\title{
Uji Kelayakan Sinbiotik (Lactobacillus plantarum) dan Limbah Ekstraksi Temulawak) sebagai Upaya Produksi Sinbiotik Rendah Kolesterol
}

\section{Properness Test of Sinbiotik (L. plantarum and Turmeric Extraction Waste) for Production of Low Cholesterol Synbiotic}

\author{
A. I. Fauzi, G. B. Pramana, M. Z. Asror dan D. Samsudewa \\ Fakultas Peternakan dan Pertanian, Universitas Diponegoro \\ Corresponding e-mail : daudreproduksi@gmail.com
}

\begin{abstract}
The aim of this research was to observe sinergity symbiotic of probiotic (L. plantarum) and prebiotic (turmeric extraction waste), endurance of $L$. Plantarum to the patogenic bacteria, acid $\mathrm{pH}$ and bile salt. Thirty six sample probiotic on agarose medium content with different percentage of turmeric extraction waste were used in livability test, four isolate of $L$. plantarum were used on bacteria challenge test and six isolate bacteria were used on the $\mathrm{pH}$ and bile salt endurance test. Data of $L$. plantarum livability were analized used analysis of variance and the other parameter were analized used descriptive qualitative. The results showed that bacteria colony number on $1 \%, 2 \%$ and $3 \%$ percentage of turmeric were $0.8 \times 10^{8}, 2.3 \times 10^{8}$ dan $1.3 \times 10^{8}$, respectively. $L$. plantarum was passed the challenge test to the Salmonella $s p$. and Staphylococcus $s p$. L. plantarum had endurance to the $\mathrm{pH} 1.5$ to 6,5 and 1 to $6 \mathrm{~mL}$ bile salt. Conclusion of the research was L. plantarum had sinergity with turmeric extraction waste to form sinbiotik low cholesterol. L. Plantarum has endurance to the Salmonella $s p$. and Staphylococcus $s p, \mathrm{pH}$ acid 1,5 to 6,5 and 1 to $6 \mathrm{~mL}$ bile salt.
\end{abstract}

Key words: turmeric extraction waste, $L$. plantarum and sinbiotic

\begin{abstract}
ABSTRAK
Tujuan dari penelitian ini adalah untuk mengetahui sinergitas simbiosis probiotik (L. plantarum) dan prebiotik (limbah ekstraksi temulawak), ketahanan $L$. plantarum terhadap bakteri patogen,pH asam dan garam empedu.Tiga puluh enam sampel probiotik dalam medium agar berisi limbah temulawak dengan persentase yang berbeda digunakan dalam uji daya hidup bakteri, Empat isolat bakteri L. plantarum digunakan dalam uji tantang bakteri dan enam isolat bakteri $L$. plantarum digunakan dalam uji ketahanan $\mathrm{pH}$ asam dan garam empedu. Data hasil penelitian daya hidup bakteri $L$. plantarum dianalisis menggunakan analisis varian, sedangkan parameter yang lain menggunakan analisis deskriptif kualitatif. Hasil penelitian menunjukkan jumlah koloni bakteri yang tumbuh pada persentase temulawak $1 \%, 2 \%$ dan $3 \%$ berturut-turut adalah $0,8 \times 10^{8}, 2,3 \times 10^{8}$ dan $1,3 \times 10^{8}$. Uji tantang bakteri L. plantarum terhadap Salmonella $s p$ dan Staphylococcus sp. menunjukkan daya tahan yang baik. Uji ketahanan $\mathrm{pH}$ asam dan garam empedu menunjukkan ketahanan $L$. plantarum pada $\mathrm{pH}$ 1,5-6,5 dan garam empedu 1-6 mL. Kesimpulan dari penelitian ini adalah L. plantarum memiliki sinergitas simbiosis dengan limbah ekstraksi temulawak untuk menyusun sinbiotik rendah kolesterol. L. plantarum juga memiliki ketahanan terhadap bakteri Salmonella sp. dan Staphylococcus sp, pH 1,5-6,5 dan garam empedu 1-6 mL.
\end{abstract}

Kata kunci : Limbah temulawak, Lactobacillus plantarum dan sinbiotik

\section{PENDAHULUAN}

Itik merupakan salah satu ternak yang diminati untuk dikembangkan oleh peternak di Indonesia. Itik merupakan jenis ternak dwiguna karena dapat menghasilkan daging dan telur. Telur itik menjadi salah satu produk itik yang sangat digemari karena memiliki rasa yang khas dan nilai gizi tinggi. Namun, telur itik memiliki kandungan kolesterol yang tinggi berkisar 824,02-880,14 $\mathrm{mg} / 100 \mathrm{~g}$ (Saty et al., 2014). Upaya menurunkan kadar kolesterol pada telur itik belum banyak dilakukan. Namun, untuk upaya menurunkan kadar kolesterol telur beberapa unggas yang lain sudah banyak dilakukan antara lain dengan penggunaan kulit bawang merah (Teru et al., 2017) dan kunyit (Putra dan Mansur, 2017). Upaya tersebut sampai saat ini belum optimum 
karena keterbatasan mekanisme penurunan koleterol.

Salah satu upaya yang dapat dilakukan untuk emngoptimumkan penurunan kolesterol adalah penggunaan sinbiotik (simbiosis antara probiotik dan prebiotik). Probiotik adalah mikroba hidup dalam jumlah yang cukup untuk mempengaruhikomposisi dan ekosistem mikroflora pencernaan (Haryati, 2011). Di lain pihak prebiotik adalah bahan makanan yang tidak dapat dicerna dan mempunyai pengaruh yang menguntungkan pada inang melalui stimulasi pertumbuhan dan atau aktivitas secara selektif terhadap satu atau beberapa jenis mikroba menguntungkan dalam pencernaan (Haryati, 2011). Sinbiotik merupakan kombinasi antara probiotik dan prebiotik yang menjadi substrat untuk mengubah mikroekologi usus sehingga mikroba yang menguntungkan akan tumbuh dengan baik. Sinbiotik dapat menurunkan kolesterol telur karena mikroba dalam probiotik selain memanfaatkan oligosakarida dalam prebiotik juga memanfaatkan kolesterol dalam saluran pencernaan untuk proses metabolismenya,sehingga akan menurunkan ketersediaan kolesterol untuk inangnya (Sari et al., 2017). Penggunaan sinbiotik harus memperhatikan kemampuan bersimbiosis antara probiotik dan prebiotik yang digunakan. Probiotik yang digunakan dalam penelitian ini adalah $L$. plantarum sedangkan prebiotiknya yaitu limbah temulawak. Oleh karena itu melalui penelitian ini dilakukan pengujian kemampuan bersimbiosis antara probiotik dan prebiotik yang digunakan, ketahanan $L$. plantarum terhadap bakteri patogen, $\mathrm{pH}$ asam dan garam empedu.

\section{MATERI DAN METODE}

Penelitian dilaksanakan pada bulan April-Juni 2018. Tempat penelitian dilaksanakan di Laboratorium Ilmu Nutrisi Pakan, Universitas Diponegoro Semarang dan Laboratorium Mikrobiologi, Universitas Muhamadiyah Semarang. Materi penelitian yang digunakan dalam uji daya hidup bakteri
L. Plantaruma dalah 36 sampel probiotik, uji tantang bakteri adalah 4 sampel isolat bakteri L. plantarum, uji ketahanan bakteri terhadap asam dan garam empedu adalah 6 sampel isolat bakteri $L$. plantarum. Peralatan yang digunakan dalam penelitian ini adalah analisis proksimat tools, shaker inkubator, vortex, osce, cawan petri dan tabung reaksi. Bahan yang digunakan dalam penelitian ini antara lain ransum itik, limbah ekstraksi temulawak, medium agar Natrium dan MRS Broth, isolat bakteri L. plantarum, sampel Salmonella sp., sampel staphylococcus sp., larutan $\mathrm{HCl} 1 \mathrm{~N}$ dan larutan oxgall.

\section{Analisis proksimat bahan pakan dan limbah ekstrak temulawak}

Penelitian ini diawali dengan pengujian kualitas ransum itik dan limbah ekstrak temulawak menggunakan analisis proksimat. Analisis proksimat yang dilaksanakan meliputi kadar air, kadar abu, kadar lemak kasar, kadar serat kasar dan kadar protein kasar.

\section{Uji Daya Hidup Bakteri L. Plantarum}

Pengujian daya hidup $L$. plantarumdimulai dari proses inkubasi bakteri dengan mengeluarkan bakteri dari pendingin untuk kemudian dihangatkan pada inkubator dengan suhu ruang yaitu pada suhu $37-41^{\circ}$ C. Selanjutnya dilakukan proses pengenceran bakteri dengan cara mencuplik stok bakteri sebanyak $1 \mathrm{~mL}$ dan dilarutkan kedalam air steril membentuk sampai dengan seri pengenceran $10-^{3} \mathrm{cfu} / \mathrm{ml}$. Larutan tersebut divortex hingga homogen. Prosedur yang sama dilakukan untuk membuat seri pengenceran sampai dengan 10-8 cfu/ml. Penambahan limbah ekstraksi temulawak pada sampel yang telah diencerkan dengan 3 perlakuan dan 12 ulangan. Perlakuan yang dilaksanakan dalam penelitian ini adalah:

T1 : Penambahan 1\% limbah ekstraksi temulawak

T2 : Penambahan 2\% limbah ekstraksi temulawak

T3 : Penambahan 3\% limbah ekstraksi temulawak 
Selanjutnya larutan dengan 10-7 $\mathrm{cfu} / \mathrm{ml}$, dan 10-8 cfu/ml masing-masing diambil sebanyak $0,1 \mathrm{ml}$ kemudian diisolasi pada media PCA dengan teknik sebar dan dilakukan secara duplo untuk setiap pengenceran. Biakan diinkubasi pada suhu $35{ }^{\circ} \mathrm{C}$ selama 48 jam. Setelah masa inkubasi, koloni bakteri yang tumbuh pada media PCA dihitung. Koloni bakteri yang tumbuh pada media agardigores dan diinkubasi pada suhu ruang selama 24 jam dan jumlah koloni bakteri yang tumbuh dihitung.

Penghitungan Total Bakteri menggunakan metode Total Plate Count (TPC) yang merupakan metode pendugaan jumlah mikroorganisme secara keseluruhan dari suatu bahan. Analisis TPC menggunakan media Plate Count Agar (PCA) dengan menanam $0,1 \mathrm{ml}$ sampel dari pengenceran ke dalam cawan petri, kemudian diinkubasi selama 48 jam pada suhu ruang (Nufus, 2016). Hasil penghitungan koloni berupa (cfu) per $\mathrm{ml} / \mathrm{g}$. Perhitungan koloni dilakukan pada seri pengenceran 10-6 cfu/ml, 10-7 $\mathrm{cfu} / \mathrm{ml}$, dan 10-8 cfu/ml. Perhitungan dilakukan dengan cara mengamati koloni bakteri yang tumbuh dalam wujud titik putih di cawan petri (Damongilala, 2009). Uji daya hidup bakteri L. plantarum ditentukan dari jumlah koloni bakteri yang terbentuk.

\section{Uji Tantang Bakteri L. plantarum}

Sampel pada uji tantang bakteri diambil dari sampel L. plantarum $s p$. dengan banyak bakteri mencapai $2.2 \times 10^{8}$. Isolat bakteri kandidat probiotik dengan konsentrasi tersebut diinokulasikan kedalam cawan petri berisi bakteri Staphylococcus sp dan Salmonella $s p$ yang banyak terdapat dalam saluran pencernaan itik. Prosedur pengujiannya dilakukan dengan metode difusi agar. Satu osce kultur bakteri uji masing-masingnya diinokulasikan kedalam media Natrium Broth (NB) $20 \mathrm{ml}$ dan diinkubasi pada suhu $30^{\circ} \mathrm{C}$ selama 18 jam sedangkan kultur stok cair L. plantarum yang berumur 24 jam diambil $1 \mathrm{ml}$ kemudian dimasukkan kedalam $10 \mathrm{ml}$ MRS broth dan diinkubasi pada suhu $300^{\circ} \mathrm{C}$ selama 18 jam. Bakteri Staphylococcus sp. dan Salmonella $s p$. diinokulasikan sebanyak $25 \mu \mathrm{l}$ kedalam NA (Nutrient Agar) secara pour plate dan dibiarkan mengeras. Sampel Lactobacillus plantarum kemudian ditanamkan pada media agar, kemudian diinkubasi pada $30^{\circ} \mathrm{C}$ selama 24 jam. Diameter zona bening yang terbentuk disekitar sumuran diukur sebagai zona penghambatan L. plantarum terhadap bakteri patogen.

\section{Uji ketahanan L. plantarum terhadap garam empedu}

Sampel BAL yang digunakan ( $L$. plantarum $\mathrm{sp}$ ) dimasukkan kedalam $50 \mathrm{ml}$ MRS dengan variasi konsentrasi garam empedu 1-6\% dengan shaker icubator pada $150 \mathrm{rpm}$ untuk masing-masing isolat. Sampel yang ditanam adalah sampel dengan konsentrasi $2,2 \times 10^{8}$ dengan metode tuang dan inkubasi pada suhu $37^{0} \mathrm{C}$ selama 1 x 24 jam sampai 4 x 24 jam. Pengamatan yang dilakukan adalah dengan metode analisis kualitatif. Kemampuan hidup bakteri dilihat dari ada tidaknya koloni yang tumbuh pada cawan petri yang telah diberi perlakuan pemberian garam empedu pada berbagai konsentrasi (Rashid et al., 2007).

\section{Uji Ketahanan $L$ • plantarum terhadap Asam}

Kultur stok cair L.plantarum yang berumur 24 jam diinokulasikan sebanyak 2 $\mathrm{ml}$ kedalam $20 \mathrm{ml}$ MRS broth dan diinkubasi pada suhu $30^{\circ} \mathrm{C}$ selama 18 jam. Hal yang sama dilakukan untuk pengujian $\mathrm{pH}$ bakteri dengan $\mathrm{pH}$ 1.5-6.5 sesuai pada bakteri pada tubuh itik (Zurmiati et al., 2014). Diambil 1 ml kultur dan dimasukkan pada $9 \mathrm{ml}$ MRS broth yang $\mathrm{pH}$ sudah diatur menjadi $\mathrm{pH}$ 1.56.5 dengan $\mathrm{HCl} 1 \mathrm{~N}$ dan diinkubasi pada suhu $30^{\circ} \mathrm{C}$ selama 24 jam. Jumlah koloni yang tumbuh diamati dengan melakukan teknik penanaman secara pour plate pada MRS agar (Analisa kualitatif) (Zavaglia et al., 1998),

\section{Analisis Data}

Analisis ragam dilakukan pada parameter daya hidup bakteri Lactobacillus plantarum. Parameter yang lain dianalisis menggunakan analisis deskriptif kualitatif. 
HASIL DAN PEMBAHASAN

\section{Analisis Proksimat Bahan Pakan dan Prebiotik}

Hasil dari analisis proksimat untuk kandungan nutrisi limbah temulawak dan ransum itik Magelang yang digunakan dalam penelitian ini dapat dilihat pada Tabel 1 .

Tabel 1. Kandungan nutrisi limbah temulawak dan ransum Itik Magelang

\begin{tabular}{|c|c|c|c|c|c|}
\hline Bahan pakan & Kadar air & $\begin{array}{c}\text { Kadar } \\
\text { abu }\end{array}$ & $\begin{array}{c}\text { Lemak } \\
\text { kasar }\end{array}$ & $\begin{array}{l}\text { Serat } \\
\text { kasar }\end{array}$ & $\begin{array}{c}\text { Protein } \\
\text { kasar }\end{array}$ \\
\hline & & & $\ldots \% \ldots$ & & \\
\hline Limbah Temulawak & 19,52 & 4,32 & 1,36 & 21,58 & 7,76 \\
\hline Ransum Itik & 8,40 & 14,19 & 8,70 & 25,47 & 19,39 \\
\hline
\end{tabular}

Ransum itik menunjukkan kualitas pakan yang baik berdasarkan protein kasarnya. Namun, ransum itik ini memiliki serat kasar yang tinggi. Kondisi ransum itik yang tinggi tersebut membutuhkan penambahan probiotik yang dapat memanfaatkan karbohidrat yang tidak tercerna (Mahdavi et al., 2005). Probiotik yang digunakan dalam penelitian ini adalah L. plantarum. Perkembangan $L$. plantarum sebagai probiotik akan lebih terdukung dengan adanya prebiotik. Prebiotik dibutuhkan karena mengandung oligosakarida sebagai sumber nutrisi mikroba (Haryati, 2011). Prebiotik yang digunakan dalam penelitian ini adalah limbah ekstraksi temulawak dari perusahaan jamu. Limbah ekstraksi temulawak selain mengandung oligosakarida juga mengandung curcumin. Curcumin diharapkan dapat membantu mengalokasikan distribusi kolesterol dalam sel epitel saluran reproduksi itik betina.

Uji daya hidup L. plantarum dalam limbah temulawak

Tabel 2. Jumlah koloni bakteri Lactobacillus plantarum yang terbentuk dalam persentase limbah ekstraksi temulawak yang berbeda

\begin{tabular}{cccc}
\hline \multirow{2}{*}{ Parameter } & \multicolumn{3}{c}{$\begin{array}{c}\text { Limbah ekstraksi } \\
\text { temulawak }\end{array}$} \\
\cline { 2 - 3 } & $1 \%$ & $2 \%$ & $3 \%$ \\
\hline Jumlah Koloni & $\ldots \ldots \ldots \ldots \ldots$ & $10^{8} \ldots \ldots \ldots \ldots \ldots$ \\
Bakteri & $0,8^{\mathrm{b}}$ & $2,3^{\mathrm{a}}$ & $1,3^{\mathrm{b}}$ \\
\hline
\end{tabular}

Hasil pengujian daya hidup $L$. plantarum dalam limbah temulawak menggunakan $1 \%, 2 \%$ dan $3 \%$ limbah temulawak dapat dilihat pada Tabel 2. Daya hidup L. Plantarum ditentukan dengan jumlah koloni yang terbentuk selama 24 jam dalam medium agar.

Hasil dari analisis ragam menunjukkan adanya perbedaan nyata $(\mathrm{P}<0,05)$ untuk jumlah koloni yang terbentuk dalam persentase limbah temulawak yang berbeda. Penambahan limbah temulawak 2\% menghasilkan total koloni bakteri yang berbeda nyata dengan persentase $1 \%$ dan $3 \%$. Namun, secara umum penambahan limbah temulawak menghasilkan pertumbuhan bakteri yang baik. Hasil ini menunjukkan bahwa probiotik L. plantarum dapat disinergikan dengan prebiotik limbah ekstraksi temulawak sehingga dapat disebut sinbiotik. Sinbiotik adalah sinergisme simbiosis antara probiotik dan prebiotik (Hamasalim, 2016).

\section{Uji Tantang Bakteri L. plantarum}

Hasil dari uji tantang bakteri $L$. plantarum menggunakan Staphyilococcus sp. dan Salmonella sp.dapat dilihat pada Gambar berikut ini.

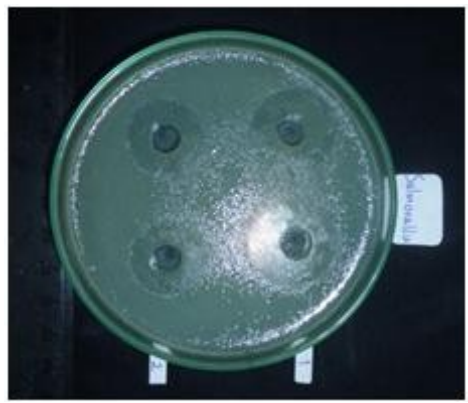




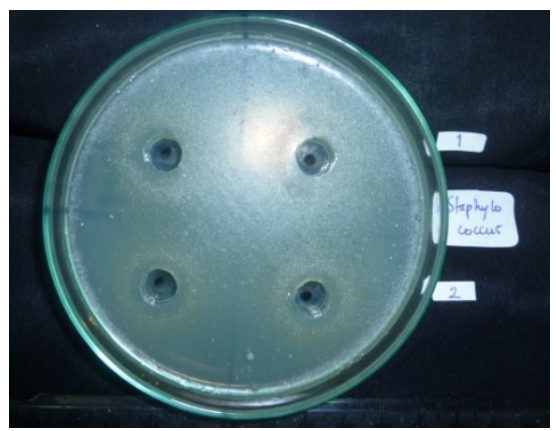

Gambar 1. Hasil uji tantang bakteri $L$. plantarum dengan Salmonella sp. dan Staphylococcus sp.

Terlihat pada gambar 1. bakteri dapat tumbuh dan membentuk koloni. Hasil tersebut secara kualitatif menunjukkan bahwa bakteri L. plantarum dapat hidup pada keadaan dimana terdapat Salmonella sp. dan Staphylococcus $s p$. Unggas sendiri banyak mengandung bakteri pembusuk Salmonella $s p$. dan Staphylococcus sp. pada pencernaannya (Gaggia et al., 2010). Dengan demikian bakteri $L$. plantarum tersebut dapat hidup pada itik lokal yang diduga pada saluran pencernaannya mengandung kedua jenis bakteri tersebut.

Pemberian probiotik L. plantarum diasumsikan dapat menghambat pertumbuhan bakteri Salmonella sp. dan Staphylococcus sp.yang dapat mempercepat proses pembusukan pada pencernaan dan hasil ternak (Setyawardhani et al., 2017). Bakteri L. plantarum sering dipakai sebagai probiotik dalam pakan ternak dikarenakan tahan terhadap bakteri pembusuk dalam tubuh unggas (Zurmiati et al., 2014).

\section{Uji Ketahanan Bakteri L. Plantarum terhadap pH Asam dan Garam Empedu}

Hasil dari uji ketahanan bakteri $L$. plantarum terhadap $\mathrm{pH}$ asam dan garam empedu dapat dilihat pada Gambar 2.

Hasil uji $\mathrm{pH}$ asam yang dilakukan terhadap bakteri asam laktat $L$. plantarum menunjukkan ketahanan pada $\mathrm{pH}$ 1,5 - 6,5. Gambar tersebut memperlihatkan bahwa terbentuk larutan keruh pada berbagai tingkat $\mathrm{pH}$ dan suspensi uji bakteri.
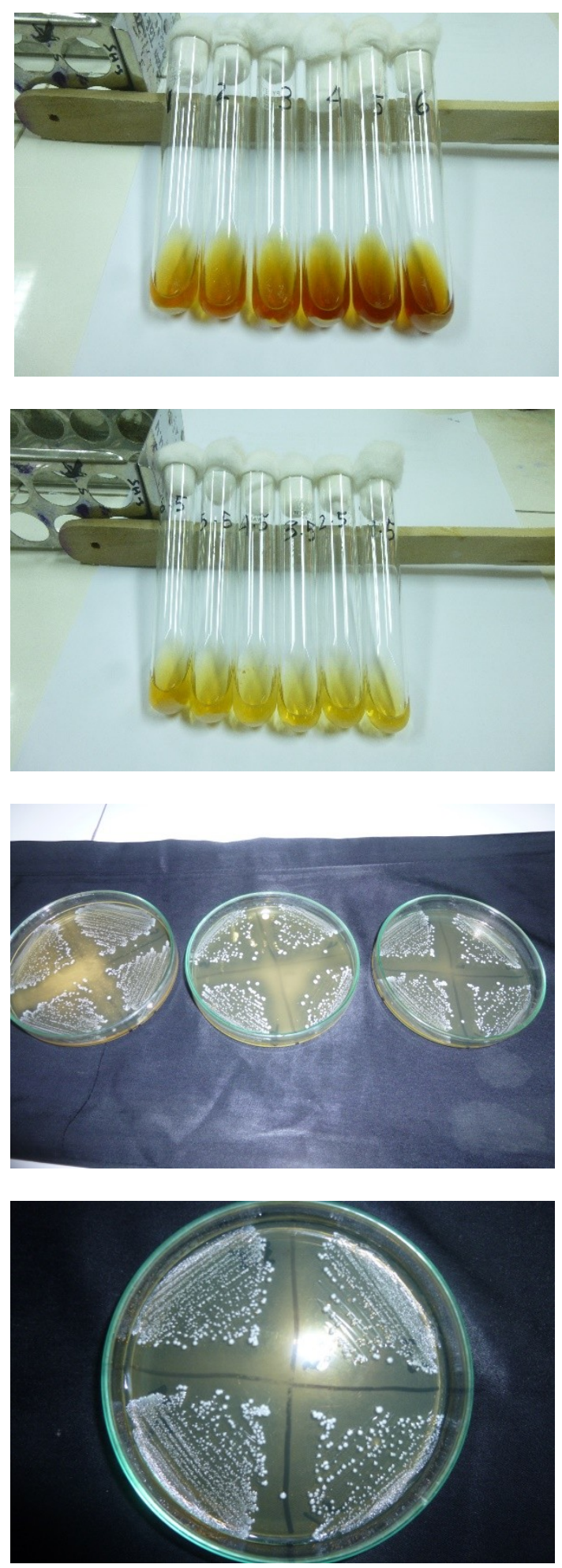

Gambar 2. hasil uji ketahanan bakteri $l$. plantarum terhadap ph asam dan garam empedu

Hasil penggoresan bakteri pada cawan petri juga menunjukkan tumbuhnya koloni L. plantarum hasil inokulasi pada uji $\mathrm{pH}$ asam 1,5-6,5 dan garam empedu 1-6 tersebut. Pertumbuhan diamati dengan 
adanya peningkatan turbiditas (kekeruhan) pada sampel. Hasil demikian memperlihatkan bahwa bakteri L. plantarum dapat bertahan pada keadaan asam dan dengan berbagai kadar garam empedu di saluran pencernaan. Ketahanan bakteri L. plantarum pada $\mathrm{pH}$ asam dan garam empedu menunjukkan ketahanannya dalam saluran pencernaan unggas (Teru, 2017).

\section{KESIMPULAN}

Kesimpulan dari penelitian ini adalah L. plantarum memiliki sinergitas simbiotik dengan limbah ekstraksi temulawak untuk menyusun sinbiotik rendah kolesterol. $L$. plantarum juga memiliki ketahanan terhadap bakteri Salmonella sp. dan Staphylococcus $s p, \mathrm{pH}$ 1,5-6,5 dan garam empedu 1-6 mL.

\section{UCAPAN TERIMA KASIH}

Terima kasih kami ucapkan kepada Direktorat Jenderal Pembelajaran dan Kemahasiswaan, Kementerian Riset, Teknologi dan Pendidikan Tinggi Republik Indonesia atas dukungannya melalui Program Kreativitas Mahasiswa Penelitian Eksakta tahun 2018. Ucapan terima kasih juga kami berikan kepada Direktorat Kemahasiswaan Universitas Diponegoro atas dukungannya.

\section{DAFTAR PUSTAKA}

Damongilala, L. J. 2009. Kadar air dan total bakteri pada ikan ROA (Hemirhampus $s p$.) asap dengan metode pencucian bahan baku berbeda. J. Ilmiah Sains 9 (2): 190-198

Gaggia, F., P. Mattarelli and B. Biavati. 2010. Probiotic and prebiotics in animal feeding for safe food production. Intl. J. Food Microbiol. 14: $515-528$.

Hamasalim, H. J. 2016. Synbiotic as feed additives relating to animal health and performance. Adv. In Microb. 6: 288302.
Haryati, T. 2011. Probiotik dan prebiotik sebagai pakan imbuhan nonruminansia. Wartazoa 21(3): 125-132.

Mahdavi, A. H., H. R. Rahmani and J. Pourreza. 2005. Effect of probiotic supplements on egg quality and laying hen's performance. Int. J. of Poultry Sci. 4 (7): 488-492.

Nufus, B. N., G. Tresnani dan Faturrahman. 2016. Populasi bakteri normal dan bakteri kitinolitik pada saluran pencernaan lobster pasir (Panulirus homarus L.) yang diberi kitosan. J. Biol. Trop. 16 (1): 15-23.

Putra, S. H. J. dan S. Mansur. 2017. Pengaruh pemberian suplemen serbuk kunyit (Currcuma longa L.) terhadap kadar kolesterol hati puyuh Jepang (Coturnix coturnix japonica L.). J. Mangif. Edu II (1): 25-31.

Rashid, M., Alam, S., Khalil and Ayub. 2007. In vitro solubilization of inorganic phosphate by phosphate solubilizing microorganisms (PSM) from maize rhizosphere. Int. J. of Agric. and Biol. (4) : 54-458.

Sari, E. M. A., E. Suprijatna dan W. Sarengat. 2017. Pengaruh sinbiotik untuk aditif pakan ayam petelur terhadap kandungan kimiawi telur. J. Petern. Ind. 19 (1): 16-22.

Saty, L., K. Praseno dan Kasiyati. 2014. Kadar kolesterol dan $\beta$-karoten telur itik dari beberapa lokasi budidaya itik di Jawa. Buletin Anatomi dan Fisiologi XXII (2): 56-63.

Teru, V., M. H. Natsir dan E. Widodo. 2017. Pemanfaatan tepung kulit bawang merah (Allium ascalonium) sebagai imbuhan pakan terhadap penampilan, profil darah dan kolesterol pada puyuh $\begin{array}{llll}\text { petelur. } & \text { JIIP. } 27 & \text { (3): 76-82. }\end{array}$ 
Zavaglia, A. G., G. Kociubinski, P. Perez, G. Zurmiati, M. E. Mahata, M. H. Abbas, D. Antoni. 1998. Isolation and characterization of bifidobacterium strains of probiotik formulation. J. Food Protect. 61(7) 865-873.

Wizna. 2014. Aplikasi Probiotik Untuk Ternak Itik. Jurnal Peternakan Indonesia. $16(2): 134-144$. 